\title{
Analysis of Market Outlet Choice by Smallholder Beef Cattle Farmers in Eswatini
}

\author{
Sicelo Ignatius Dlamini \\ Department of Tropical Agriculture and International Cooperation, National Pingtung University of Science \\ and Technology \\ 1, Shuefu Road, Neipu, Pingtung 91201, Taiwan \\ E-mail: revsicelodlamini@gmail.com \\ Wen-Chi Huang* \\ Department of Agribusiness Management, National Pingtung University of Science and Technology \\ 1, Shuefu Road, Neipu, Pingtung 91201, Taiwan \\ E-mail: wenchi@mail.npust.edu.tw
}

\begin{abstract}
Beef cattle marketing assumes a central position in the rural development discussion and economic growth in Eswatini. However, scantiness in empirical assessment on market outlet choice undercuts the establishment of propoor market systems for improved livelihoods. Therefore, this study sought to determine the drivers of beef cattle market outlet choice. The Snowball-purposive sampling technique was conducted to collect data, through personal interviews guided by a structured questionnaire, from a sample of 328 farmers. Descriptive statistics and multinomial logit regression were used for data analysis. The results indicate that $51.83 \%, 42.38 \%$ and $5.79 \%$ of the farmers marketed through the processor-butcher, direct and feedlotter outlets, respectively. Education and exotic breeds were associated with the feedlotter outlet. Vectors of marketing and production-related factors are the main drivers of market outlet choice. Pasture availability revealed statistical significance at $p<0.01$, while off-farm employment and cooperative membership were significant at $p<0.05$. The proportions of cows and oxen in the herd were significant at $p<0.1$. The study recommends farmer-training and protection of pastures to advance selection of formal outlets. Cooperativism is a suggested mechanism for creating farmers' bargaining power. A conducive market framework is required for the promotion of formal market outlets.
\end{abstract}

Keywords: market outlet choice, beef cattle, multinomial logit model, Eswatini

DOI: $10.7176 / \mathrm{JESD} / 11-8-03$

Publication date: April $30^{\text {th }} 2020$

\section{Introduction}

Eswatini is an agrarian-based economy, where livelihoods of the majority (70\%) are dependent on small-scale agriculture in rural areas. Common in sub-Saharan Africa, smallholder agriculture remains a plausible avenue for rural and national economic growth (Zivenge \& Karavina, 2012). The livestock subsector, dominated by smallholder farmers (Department of Veterinary and Livestock Services, 2018b), remains the major contributor $(4.4 \%)$ to the gross domestic product contributed by the primary sector $(8.6 \%)$ to national gross domestic product (Central Statistics Office, 2018).

In this regard, beef cattle farming and marketing have assumed central positions in the rural development discussion in the country. However, the sub-subsector has not received empirical analysis with respect to the drivers of market channel choice by farmers, with recent work focusing on market participation (Dlamini \& Huang, 2019). The dawn of agricultural market liberalization in livestock products injected market competition for domestic products, affecting the domestic market mechanisms and marketing outlet options (Xaba \& Masuku, 2013). Furthermore, domestic and export beef demand continues to increase (Department of Veterinary and Livestock Services, 2018a), exonerating beef cattle farming into a prospective agribusiness avenue. Unfortunately, farmers in Eswatini have not yet derived full benefit from this enterprise (Mabuza, Ortmann, \& Wale, 2014). Therefore, empirical assessment on market outlet choice provides vital information for the identification, establishment and promotion of pro-poor livestock market systems that abate marketing cost (Girma \& Abebaw, 2012). This is essential in the creation of market incentives that contribute to the amelioration of farmers' livelihoods through participation in intensive formal market outlets. Therefore, this study sought to:

i. Describe the farmers' socioeconomic characteristics in relation to the selected market outlets.

ii. Determine the drivers of beef cattle market outlet choice among the farmers.

\section{Literature review}

\subsection{Agricultural markets and marketing}

Agricultural markets are often grouped into formal in informal markets. Informal market outlets concern the flow of farm produce directly from the farm to the consumer through farm gate sales, roadside sales, etc. (Aguglia, De 
Santis, \& Salvioni, 2009). This type of market is distinguished by unofficial trade agreements, seasonality and information asymmetry due to paucity of market information (Coetzee, Montshwe, \& Jooste, 2005). Conversely, formal markets involve various economic agents coordinated through formal linkage relationships (contracts). Hao et al. (2018) underscored the difficulties encountered by smallholder farmers in penetrating this market type. This is attributed to the cost embedded in the stipulated product and market standards demanded (Chalwe, 2011), to which collective action among farmers is suggested as cogent solution.

Physical agricultural markets play a vital role in the transfer of farm produce to consumers over time and space (Tefera, 2014), which allows farmers to limit the cost and time spent scouting agricultural produce. Contrary, virtual market outlets create the problem of market information asymmetry that deprive farmers of market information that is imperative for price setting. This imposes loss in bargaining power, which forces farmers to succumb to lower market prices. In Eswatini, the dearth of market organization and information dispensation has propagated power asymmetry that forces smallholder farmers to succumb to passable prices. This has induced market failure that undermines the potential of agricultural markets in addressing food security and poverty alleviation (Xaba \& Masuku, 2013).

A market channels is a set of interdependent economic agents that ensures the availability of products for consumption (Hao et al., 2018). Longer market outlets have been found to add more margins (Ndoro, Mudhara, \& Chimonyo, 2015), thus apportioning small end-product value to farmers. In contrast, shorter market channels eliminate middlemen intermediaries, apportioning high producers' share to farmers. This is fundamental in the improvement of rural livelihoods through increased farmers' income. Short channels, often called direct markets, also allow for farmer-consumer interactions for the advancement of customer satisfaction through the provision of high-quality products. Hence, short market outlet channels are often popular than longer formal outlets in agricultural marketing (Gong, Parton, Zhou, \& Cox, 2006).

\subsection{Overview of cattle marketing in Eswatini}

Beef cattle marketing in Eswatini operates under a free market economy structure, where there are no controls to synchronize interaction activities between trading partners (Agbeko, 2015; Greaves, 1975). Farmers, majority of whom are smallholders in rural areas, engage in the voluntary economic activities of production and marketing of beef cattle. Cattle marketing is basically through virtual markets (Dlamini \& Huang, 2019), where transactions are mainly for two reasons; sourcing breeding stock and slaughtering for beef production.

Importation provides an alternative source of breeding stock and the supply of unprocessed beef carcasses and processed beef products. Live cattle imports are usually high-quality exotic breeds that are progeny-tested for high performance and carcass quality, mainly from South Africa. The Ministry of Agriculture facilitates import permits, port of entry inspections and quarantine services to enforce high phytosanitary conditions (Government of Eswatini, 1965).

Domestic cattle marketing follows an indeterminate market structure (Mailu et al., 2012) through face-to-face bargaining based on physical livestock characteristics. Figure 1 presents a diagrammatic outline of the beef cattle and beef marketing structure in Eswatini for the 2018 financial year. 


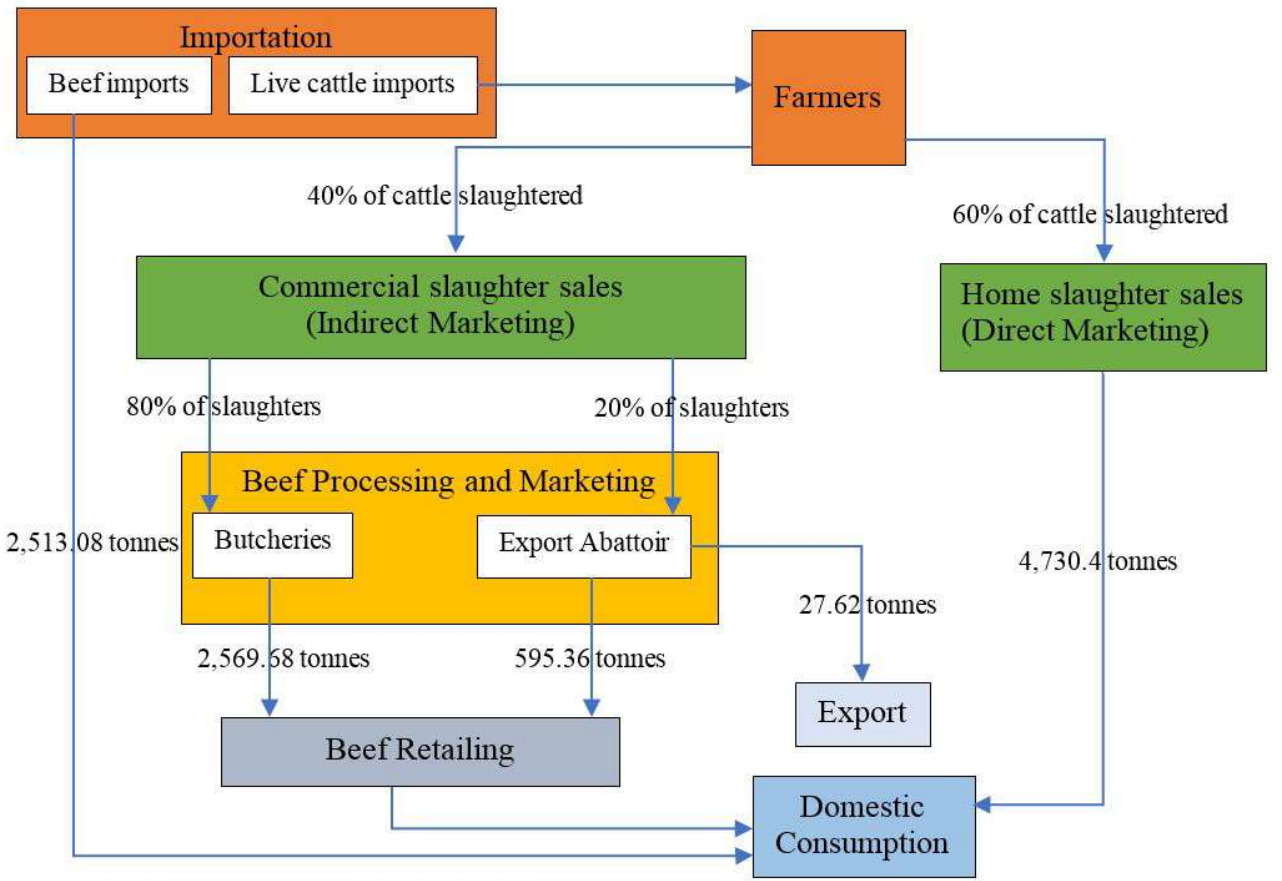

Figure 1. Diagrammatic presentation of beef cattle and beef marketing in 2018.

Source: Adapted from Department of Veterinary and Livestock Services (2018a)

Figure 1 indicates that beef market channels are grouped into direct and indirect markets. Direct market outlets represent informal outlets that allow for the transaction of cattle between farmers and consumer (Aguglia et al., 2009 ), to provide beef through home slaughters. This category accounted for the largest proportion, $60 \%$, of domestically produced beef from 26,280 beef cattle slaughters in 2018. Homes slaughters are common during family functions such as parties, ceremonies and funerals. This type of market channel can also be understood as spot marketing (Fertö \& Szabó, 2002). The dominance of the direct market outlet could be attributed to the gain in appreciable levels of market information for better-price negotiations (Mutura, Nyairo, Mwangi, \& Wambugu, 2015).

On the other hand, indirect cattle marketing (formal markets) involves the sale of cattle to entities such as processors, who in turn transfer end products to retailers such as supermarkets (Blandon, Henson, \& Islam, 2009). In Eswatini, cattle off-take through formal market outlets is subordinate to direct channels, accounting for $40 \%$ slaughters and producing 33\% less beef compared to the informal market channel. Similar note was made by Shiimi, Taljaard, and Jordaan (2012) for cattle marketing in North-Central Namibia, underscoring the argument that smallholder farmers in developing economies encounter numerous difficulties in penetrating such market outlets (Hao et al., 2018). Although transactions emanate under a state of "no integration" due to lack of formal linkage relationships between upstream (farmers) and downstream (processors and retailers) economic agents, market imperfection (Woldie \& Nuppenau, 2009) imposes a superiority-subordinate structure that resembles vertical integration. Moreover, the formal strategic alliance through contracts across some production and marketing segments, feedlotters and the export abattoir, captures the sense of vertical coordination through the formal market outlets (Mutura et al., 2015).

\section{Methodology}

\subsection{Study area}

Eswatini is a monarchical country in southern Africa, mainly surrounded by the Republic of South Africa and Mozambique on the east. National population stands at about 1.2 million, with $70 \%$ of the population reliant on subsistence small-scale agriculture in rural areas. About $63 \%$ of the population live below the poverty line, the majority of whom are smallholder farmers in rural areas. Being an agrarian country, agriculture remains a prospective livelihoods improvement avenue since the unemployment rate remains above $40 \%$ (Ministry of Labour and Social Security, 2013/14).

The study was conducted over the Hhohho, Lubombo, Manzini and Shiselweni regions. Cattle marketing is virtual, with few physical auction yards that are only active during severe winters and drought periods in some districts. Beef cattle farming is most suitable for the Highveld, Middleveld and Lubombo climatic zones that receive sufficient rain for pasture growth (FAO, 2005). The grasses in the Lowveld are highly palatable, but 
recurrent droughts have relegated the climatic zone to be non-suitable for large ruminant production.

\subsection{Sampling procedure and Data Collection}

The targeted population was smallholder beef cattle farmers in the four administrative districts of the study area. Due to the lack of the sampling frame, the study used a purposive two-stage stratified sampling technique. The first stage involved stratifying farmers according to the districts. The snowballing sampling method was then applied to select 328 farmers from the strata. Our sample size was larger than the sample sizes of related studies in the region (Dlamini-Mazibuko, Ferrer, \& Ortmann, 2019; Mutura et al., 2015; Shiimi et al., 2012; Xaba \& Masuku, 2013; Zivenge \& Karavina, 2012). The sample size distribution is presented in Table 1.

Table 1. Sample size distribution.

\begin{tabular}{lcc}
\hline Region & Number of Samples & Percentage Proportion of Sample \\
\hline Hhohho & 103 & 31.4 \\
Lubombo & 81 & 24.7 \\
Manzini & 91 & 27.7 \\
Shiselweni & 53 & 16.2 \\
\hline Total & $\mathbf{3 2 8}$ & $\mathbf{1 0 0}$ \\
\hline
\end{tabular}

Personal interviews, guided by a structured questionnaire, were conducted to collect primary data from farmers. The three-section questionnaire was pre-tested and unnecessary variables were deleted, while necessary variables were incorporated. Section I focused on cattle production information; Section II was designated for cattle marketing information, while Section III collected data on socioeconomic characteristics of the farmers and public goods and services factors related to beef cattle production and marketing.

\subsection{Conceptual Framework}

Rational market participants self-select market channel outlets that reward maximized incentives (Ndoro et al., 2015). The market outlet choice decision (MOC) is a dependent variable with $J$ number of market outlet alternatives. MOC is a utility maximization function of observed market prices (P) and a vector of transaction costs (De Bruyn, De Bruyn, Vink, \& Kirsten, 2001; Hobbs, 1997).

Transaction cost involves the observable and virtual costs embedded in a successful market transaction (Mabuza et al., 2014; Verhaegen \& Van Huylenbroeck, 2001). It is captured through farmers' socioeconomic characteristics (FS), public goods and services (Emana, Ketema, Mutimba, \& Yousuf, 2015) and market outletrelated factors (MF). Spatial and economic factors vary among farmers, inducing heterogeneity in marketing costs (Ngarava, Phetshe, \& Mushunje, 2019), thus influencing the market outlet choice decisions.

FS is a union set of farmer, household and location-specific theoretical sources of marketing cost that influence the choice of market outlet (Barrett, 2008). Farmer-specific characteristics capture the human-capital effect and mitigation strategies involved in the cost of searching for market information, bargaining skills and monitoring costs (Gong et al., 2006). Household-specific features capture production and marketing skills that affect the choice of market outlet.

MF capture characteristics such as market distance, market information, etc., which influence marketing cost (Emana et al., 2015). Timeliness, short and/or longer payment durations (Gong, Parton, Cox, \& Zhou, 2007), and accuracy in market-related factors influence the farmer's decision on where to sell his/her cattle. Public goods and services (PGS) involve livestock institutional factors (Coetzee et al., 2005) that support the production and marketing of high-quality cattle, such as pastures, farm credit and cooperatives that strengthen the farmers' economic position (Bijman \& Iliopoulos, 2014).

Since the ultimate market incentive, $\mathrm{P}$, is influenced by the quality of cattle sold, we introduced productionrelated factors (PF) that influence the farmers' decision on market outlet choice (Hao et al., 2018; Mafukata, 2015). Moreover, optimization of market outlet utility is cattle marketing is achieved through selling different classes of cattle (cows, heifers, steers, oxen, etc.) to suitable outlets. Hence, the novelty of this study is further improved through the inclusion of a vector of herd features (HF) that influence the farmers' market outlet choice decision (Gillespie, Basarir, \& Schupp, 2004). Therefore, the reduced model for the farmers' market outlet choice decision was expressed as:

$$
M O C=f(P, F S, M F, P G S, P F, H F)
$$

Where: $\mathrm{MOC}=$ market outlet choice; $\mathrm{P}=$ price; $\mathrm{FS}=$ farmer socioeconomic characteristics; $\mathrm{MF}=$ market-related factors; PGS = public goods and services; PF = production-related factors; and HF = herd features.

\section{4 Data Analysis}

3.4.1 Descriptive analysis

Descriptive statistics were used to describe the socioeconomic characteristics of farmers in relation to the selected market outlets. Such descriptive statistics consisted of means, standard deviation, frequencies and percentages. 


\subsubsection{Econometric analysis}

Given the free market conditions in beef cattle marketing (Blandon et al., 2009), farmers' choice decision analysis is founded on the rational choice theory (Soe, Moritaka, \& Fukuda, 2015), with the assumption that individual farmers choose a market alternative that maximizes utility from a set of mutually exclusive market outlet alternatives. The conceptualisation of each farmer's choice can be expressed using the random utility model for discrete choice decisions (Greene, 2012). Here, a farmer with unique features allocates average utility to the market outlet of choice, within the set of alternative outlets.

Since the beef cattle market outlets are mutually exclusive, an $i$ th farmer is faced with $J$ alternative market outlets, generating a decision based on maximized utility after conducting a benefit-marginal cost analysis (Verhaegen \& Van Huylenbroeck, 2001). Hence, the utility of selecting an outlet, $j$, can be expressed as (Soe et al., 2015):

$$
U_{i j}=\beta^{\prime} X_{i j}+\varepsilon_{i j}
$$

Here, $U_{i j}$ represents $i$ th farmers' utility derived from choosing outlet $j$. $X_{i j}$ denotes the vector of explanatory variables, $\beta$ represents the vector of parameter estimates associated with the explanatory variable, and $\varepsilon_{i j}$ is the random disturbance term.

Since a farmer chooses a marketing outlet alternative based on utility maximization (Wooldridge, 2013), the utility of the selected market outlet should be the largest amongst the utilities that can be derived from the other alternative outlets. Therefore, the probability of the selected market outlet, $j$, can be statistically presented as:

$$
\text { Probability }\left[U_{i j}>U_{i k}\right] \text { for all } k \neq j
$$

If we represent the farmers' choice decision with $Y_{i}$, considering that the disturbances associated with a selected market outlet, $j$, are identically and independently distributed, the Logit Regression Model (LRM) can be specified (Tesfamariam, Berhanu, \& Afera, 2015). For dichotomous dependent variables, the Binary Logit Model is used (Mutura et al., 2015), whereas the Multinomial Logit Model (MNL) is adopted for polychotomous decision variables (Hoffman \& Duncan, 1988), such as our study with three alternatives (1: selling to the feedlotter, 2: selling to the processor-butcher and 3: selling directly to consumers). Hence, the probability of the $i$ th farmer to select the utility maximizing market outlet is expressed as:

$$
\operatorname{Prob}\left(Y_{i}=j\right)=\frac{\exp \beta_{j}^{\prime} x_{i}}{\sum_{j=0}^{J} \exp \left(\beta_{j}^{\prime} X_{i}\right)}, \text { for } j=1,2,3
$$

Where: $\operatorname{Prob}\left(Y_{i}=j\right)$ is the probability that a farmer chooses market outlet $j, X_{i}$ is the vector of explanatory variables and $\beta_{j}$ is the vector of parameter estimates associated with market outlet $j$. If the high-frequency market outlet alternative (processor-butcher) is used as a reference group and $\beta_{2}=0$, the probability of the remaining market outlets, 1 and 3 is given by:

$$
\operatorname{Prob}\left(Y_{i}=j \mid x_{i}\right)=\frac{\exp \left(\beta_{j}^{\prime} x_{i}\right)}{1+\sum_{j=0}^{j} \exp \left(\beta_{j}^{\prime} x_{i}\right)} \text { for all } j>0
$$

Since the interpretation of MNL coefficients is not straight forward, marginal effects are computed to measure the magnitude of the expected change in probability of selecting a market outlet given a unit change in an explanatory variable. The marginal effects are partial derivatives of the probability of choosing a market outlet and are derived as (Hailu \& Fana, 2017):

$$
\delta_{i}=\frac{\partial P_{j}}{\partial X_{j}}=P_{j}\left[\beta_{j}-\sum_{j=1}^{j} P \beta_{j}\right]=P_{j}\left[\beta_{j}-\bar{\beta}\right]
$$

Where: $P$ represents the likelihood associated with the market outlet alternatives, and $\beta_{j}$ denotes the parameter estimates associated with the explanatory variables. For purposes of our analysis, the empirical Multinomial Logit Model was specified as:

Market Outlet Choice $=\beta_{0}+\beta_{1}$ Age $+\beta_{2}$ Education $+\beta_{3}$ Gender $+\beta_{4}$ MaritalStatus $+\beta_{5}$ Expereince + $\beta_{6}$ HouseholdSize $+\beta_{7}$ OffFarmEmployment $+\beta_{8}$ PastureAvailability $+\beta_{9}$ AccessFarmCredit + $\beta_{10}$ CooperativeMembership $+\beta_{11}$ MarketDistance $+\beta_{12}$ SourceMarketInformation + $\beta_{13}$ MarketingCost $+\beta_{14}$ NoCattleSold $+\beta_{15}$ Price $+\beta_{16}$ SaleDuration $+\beta_{17}$ PriceSetting + $\beta_{18}$ TotalCost $+\beta_{19}$ NoLabourers $+\beta_{20}$ ValueHerdSize $+\beta_{21}$ SupplementFeed $+\beta_{22}$ Medicines + $\beta_{23}$ BreedType $+\beta_{24}$ CalvingRate $+\beta_{25}$ Cows $+\beta_{26}$ Heifers $+\beta_{27}$ Steers $+\beta_{28}$ Oxen $+\varepsilon_{i}$

\section{5 Diagnostic Tests for Multinomial Logit Model}

The econometric estimation procedure requires control of multicollinearity among explanatory variable in order to generate parameter estimates that are non-biased. A combination of the variance inflation factor (VIF) and bivariate correlation matrix analyses were conducted to identify collinear continuous variables. For categorical variables, contingency table analysis, chi-square tests, lambda and symmetric measures (Phi, Cramer's V and Contingency Coefficient) were applied to identify collinearity. All variables that reflected collinearity were eliminated from the model. Moreover, Stata Version 15 was also set to eliminate collinear variables. Potential sources of heteroscedasticity were suppressed by the use of the robust standard error associated with the estimated 
coefficients of the explanatory variables. Table 2 presents the empirical model explanatory variables with their hypothesized relationship with the dependent variable.

Table 2. Hypothesized signs for variables used in the Multinomial Logit Model.

\begin{tabular}{|c|c|c|c|c|}
\hline \multirow[t]{2}{*}{$\begin{array}{l}\text { Independent } \\
\text { variable }\end{array}$} & \multirow[t]{2}{*}{ Measurement } & \multicolumn{3}{|c|}{$\begin{array}{l}\text { Dependent variable: Market Outlet } \\
\text { Choice }\end{array}$} \\
\hline & & Feedlotter & $\begin{array}{l}\text { Processor- } \\
\text { Butcher }\end{array}$ & Direct \\
\hline \multicolumn{5}{|c|}{$\begin{array}{c}\text { Farmer Socioeconomic Characteristics } \\
\end{array}$} \\
\hline Age & Age of farmer in years & - & $+/-$ & + \\
\hline Education & Formal schooling years & $+/-$ & $+/-$ & + \\
\hline Gender & $0=$ Female, $1=$ Male & + & + & + \\
\hline Marital status & $0=$ Single, $1=$ Married & - & + & + \\
\hline Experience & No. of years as herd owner & + & + & + \\
\hline Household size & No. of people in household & $+/-$ & + & $+/-$ \\
\hline $\begin{array}{l}\text { Off-farm } \\
\text { employment }\end{array}$ & $0=\mathrm{No}, 1=\mathrm{Yes}$ & + & + & $+/-$ \\
\hline \multicolumn{5}{|c|}{ Public Goods and Services } \\
\hline Pasture availability & $0=$ Insufficient, $1=$ Sufficient & + & + & + \\
\hline Access farm credit & $0=$ No, $1=$ Yes & $+/-$ & $+/-$ & + \\
\hline $\begin{array}{l}\text { Cooperative } \\
\text { membership }\end{array}$ & $0=\mathrm{No}, 1=$ Yes & $+/-$ & + & + \\
\hline \multicolumn{5}{|c|}{ Price and Marketing Factors } \\
\hline Market distance & Farm to buyer's premises, $\mathrm{km}$ & - & - & - \\
\hline Source market info. & $0=$ Formal, $1=$ Informal & + & + & + \\
\hline Marketing cost & Direct cost of marketing in $\mathrm{E}$ & - & - & - \\
\hline Cattle sold & No. of cattle sold & + & + & $+/-$ \\
\hline Price & Av. price received from buyer & + & + & + \\
\hline Sale duration & $0=>2$ weeks, $1 \leq 2$ weeks & - & - & - \\
\hline Price setting & $0=$ Assisted, $1=$ Own experience & $+/-$ & $+/-$ & $+/-$ \\
\hline \multicolumn{5}{|c|}{ Production-related Factors } \\
\hline Total cost & Sum of variable costs in $\mathrm{E}$ & + & + & $+/-$ \\
\hline Labourers & No. of herd boys & + & + & + \\
\hline Herd size & Value of herd size in $\mathrm{E}$ & + & $+/-$ & + \\
\hline Supplement feed & Amount, kg, of feed bought & + & + & - \\
\hline Medicine & Volume, ml, of medicines used & + & + & $+/-$ \\
\hline \multicolumn{5}{|c|}{ Herd Features } \\
\hline Breed type & $0=$ Nguni, $1=$ Crosses & + & + & - \\
\hline Calving rate & $\begin{array}{l}\text { No. of live calves as proportion of pregnant } \\
\text { cows at the start of the season }\end{array}$ & + & + & + \\
\hline Cows & $\begin{array}{l}\text { Total cow value, E, as proportion of herd size } \\
\text { value }\end{array}$ & + & + & + \\
\hline Heifers & $\begin{array}{l}\text { Total heifer value, E, as proportion of herd } \\
\text { size value }\end{array}$ & + & + & + \\
\hline Steers & $\begin{array}{l}\text { Total steer value, E, as proportion of herd size } \\
\text { value }\end{array}$ & + & + & $+/-$ \\
\hline Oxen & $\begin{array}{l}\text { Total oxen value, E, as proportion of herd size } \\
\text { value }\end{array}$ & + & + & $+/-$ \\
\hline
\end{tabular}

Note: E - Emalangeni, the currency of Eswatini.

\section{Results and Discussion}

\subsection{Descriptive analysis}

The processor-butcher market outlet is a cluster of beef producers with the processing and marketing functions, sourcing cattle from farmers. The results (Table 3) reveal a high frequency for farmers that transact their cattle through the processor-butcher outlet, with a sample overall percentage of $52 \%(s=170)$. This outlet is the main supply route for commercial beef to meet domestic and export demand, hence was used as a reference group for the econometric analysis. About $42 \%(\mathrm{~s}=139)$ of the sampled farmers marketed cattle through the direct market outlet, and only $6 \%(\mathrm{~s}=19)$ of the farmers used the feedlotter outlet. The high-frequency subgroup was found to be farmers from the Hhohho region that marketed through the processor-butcher $(s=62)$. 
Table 3. Proportion of farmers according to the market outlet used ( $\mathrm{S}=328)$.

\begin{tabular}{|c|c|c|c|c|c|c|c|c|c|c|}
\hline \multirow[t]{3}{*}{ Market Outlet } & \multicolumn{8}{|c|}{ Region } & \multicolumn{2}{|c|}{ Total } \\
\hline & \multicolumn{2}{|c|}{ Hhohho } & \multicolumn{2}{|c|}{ Lubombo } & \multicolumn{2}{|c|}{ Manzini } & \multicolumn{2}{|c|}{ Shiselweni } & & \\
\hline & Freq. & $\%$ & Freq. & $\%$ & Freq. & $\%$ & Freq. & $\%$ & Freq. & $\%$ \\
\hline Feedlotter & 2 & 1.94 & 6 & 7.41 & 9 & 9.89 & 2 & 3.77 & 19 & 5.79 \\
\hline Processor-Butcher & 62 & 60.19 & 35 & 43.21 & 42 & 46.15 & 31 & 58.49 & 170 & 51.83 \\
\hline Direct sale & 39 & 37.86 & 40 & 49.38 & 40 & 43.96 & 20 & 37.74 & 139 & 42.38 \\
\hline Overall & 103 & 100 & 81 & 100 & 91 & 100 & 53 & 100 & 328 & 100 \\
\hline
\end{tabular}

4.1.1 Farmer Socioeconomic Characteristics

Table 4 depicts that the average age of the farmers does not vary among the different categories of the dependent variables. However, the minimum and maximum ages for the feedlotter outlet are highest, 40 and 88, compared to the other groups. This indicates that older farmer tend to market through the feedlotter outlet.

The results further reveal that the farmers that marketed through the feedlotter are the most educated group compared to other groups, with an average of 11 years of formal education. This is attributed to the sorting and grading required for cattle categorisation based on classes and body condition before selling to the feedlotter. Attracting good prices from the feedlotter requires the selecting of cattle with high potential of feed conversion, a skill dependent on literacy levels of the farmers. This finding captures the importance of education in the shift towards intensive commercial cattle farming in the country. The average household size does not vary according to the market outlet alternatives.

Table 5 shows that the majority, $72 \%(s=235)$, of the sampled farmers were males. This is because the male household head is the traditional owner of the cattle herd and beef cattle farming is a designate farming activity ascribed to the male gender in Eswatini. Amongst the feedlotter suppliers, 84\% ( $\mathrm{s}=16$ ) were males, compared to $72 \%(\mathrm{~s}=123)$ and $69 \%(\mathrm{~s}=96)$ of male that supplied the processor-butcher and direct market outlets, respectively. Among females, majority, $\mathrm{s}=47$ (51\%), supplied the processor-butcher followed by the direct market outlet, $\mathrm{s}=43$ $(46 \%)$, and the feedlotter, $\mathrm{s}=3(16 \%)$. Females have been found to avoid market alternatives that demand more bargaining power and pricing experience (Girma \& Abebaw, 2012). Overall, the high-frequency group is males that marketed through the processor-butcher.

It is a norm that after the demise of the male household head, family members liquidate the livestock enterprise since the remaining female spouse usually lacks the knowhow and desire to look after big livestock. This is assumed to have induced the high married frequency $(73 \%)$ in the sample. Majority of sampled farmers, $\mathrm{s}=204(73 \%)$, were married, out of which majority of them $(\mathrm{s}=127)$ market cattle through the processor-butcher. Majority of the farmers ( $\mathrm{s}=103$ ) were engaged in off-farm employment and marketed cattle through the processorbutcher. Amongst the farmers that marketed through the direct outlet, 54\% $(\mathrm{s}=75)$ were engaged in off-farm employment, whereas 46\% (64) were unemployed. Moreover, majority of the employed farmers sold through the fast-transaction outlets, feedlotter (74\%) and processor-butcher $(61 \%)$ since they do not have sufficient time for scouting buyer through the direct market outlet (Hao et al., 2018).

Table 4. Descriptive statistics for socioeconomic continuous variable ( $S=328)$.

\begin{tabular}{llcccc}
\hline Variable & Market Outlet & Mean & Std. Dev. & Min. & Max. \\
\hline Age & Feedlotter & 59.368 & 11.127 & 40 & 88 \\
& Processor-Butcher & 58.700 & 12.416 & 28 & 87 \\
& Direct & 58.158 & 12.753 & 22 & 87 \\
& Overall & $\mathbf{5 8 . 5 0 9}$ & $\mathbf{1 2 . 4 5 9}$ & $\mathbf{2 2}$ & $\mathbf{8 8}$ \\
\hline Education & Feedlotter & 11.421 & 4.476 & 2 & 22 \\
& Processor-Butcher & 9.835 & 4.576 & 1 & 19 \\
& Direct & 8.439 & 4.150 & 1 & 17 \\
& Overall & 9.335 & 4.463 & 1 & 22 \\
\hline Household size & Feedlotter & 8.421 & 4.004 & 4 & 18 \\
& Processor-Butcher & 8.371 & 3.782 & 2 & 28 \\
& Direct & 8.432 & 4.127 & 2 & 23 \\
& Overall & $\mathbf{8 . 3 9 9}$ & $\mathbf{3 . 9 3 2}$ & $\mathbf{2}$ & $\mathbf{2 8}$ \\
\hline
\end{tabular}


Table 5. Descriptive statistics for socioeconomic categorical variables $(\mathrm{S}=328)$.

\begin{tabular}{|c|c|c|c|c|c|c|c|c|c|}
\hline \multirow[t]{3}{*}{ Variable } & \multirow[t]{3}{*}{ Category } & \multicolumn{6}{|c|}{ Market Outlet } & \multicolumn{2}{|c|}{ Total } \\
\hline & & \multicolumn{2}{|c|}{ Feedlotter } & \multicolumn{2}{|c|}{ Processor-Butcher } & \multicolumn{2}{|c|}{ Direct } & & \\
\hline & & Freq. & $\%$ & Freq. & $\%$ & Freq. & $\%$ & Freq. & $\%$ \\
\hline \multirow[t]{3}{*}{ Gender } & Female & 3 & 15.79 & 47 & 27.65 & 43 & 30.94 & 93 & 28.35 \\
\hline & Male & 16 & 84.21 & 123 & 72.35 & 96 & 69.06 & 235 & 71.65 \\
\hline & Overall & 19 & 100 & 170 & 100 & 139 & 100 & 328 & 100 \\
\hline \multirow[t]{3}{*}{ Marital Status } & Single & 2 & 10.53 & 43 & 25.29 & 43 & 30.94 & 88 & 26.83 \\
\hline & Married & 17 & 89.47 & 127 & 74.71 & 96 & 69.06 & 240 & 73.17 \\
\hline & Overall & 19 & 100 & 170 & 100 & 139 & 100 & 328 & 100 \\
\hline Off-Farm & No & 5 & 26.32 & 67 & 39.41 & 64 & 46.04 & 136 & 41.46 \\
\hline \multirow[t]{2}{*}{ Employment } & Yes & 14 & 73.68 & 103 & 60.59 & 75 & 53.96 & 192 & 58.54 \\
\hline & Overall & 19 & 100 & 170 & 100 & 139 & 100 & 328 & 100 \\
\hline \multirow[t]{3}{*}{ Breed type } & Nguni & 6 & 31.58 & 71 & 41.76 & 90 & 64.75 & 167 & 50.91 \\
\hline & Crosses & 13 & 68.42 & 99 & 58.24 & 49 & 35.25 & 161 & 49.09 \\
\hline & Overall & 19 & 100 & 170 & 100 & 139 & 100 & 328 & 100 \\
\hline
\end{tabular}

Majority of the sampled farmers kept the native small-sized Nguni breed, $s=167$ (51\%). Amongst these farmers, $90(54 \%)$ marketed through the direct outlet. This is due to the fact that beef quality is not of major concern, compared to the formal commercial beef outlets (feedlotter and processor-butcher). Among the farmers that kept hybrid crosses, $70 \%$ (112) supplied the feedlotter and processor-butcher outlets, revealing the importance of the exotic high-quality breeds on commercial beef production in Eswatini. This is attributed to the high growth rate and feed conversion rate of crosses, promoting their suitability for the feedlotting exercise and production of high-quality beef for fresh meat domestic and export supply. The overall high-frequency group was farmers that kept crosses and supplied the processor-butcher.

4.1.2 Public Goods and Service

Table 6 indicates that the majority of the sampled farmers, $s=175(53 \%)$, had sufficient pastures for cattle production. The overall high-frequency group, $\mathrm{s}=103$, was farmers with sufficient pastures that marketed cattle through the processor-butcher. Hence, protecting pastures from invasive weeds and human settlement is critical for the shift towards commercial farming that has high potential for ameliorating rural livelihoods.

The results further indicate that the majority of the sampled farmers, s=273 (83\%), lack access to farm credit. Among these farmers, $48 \%(\mathrm{~s}=132)$ and $45 \%(\mathrm{~s}=124)$ marketed cattle through the processor-butcher and the direct outlet, respectively. Furthermore, 93\% $(\mathrm{s}=305)$ of the sampled farmers are not members of agricultural cooperatives. This explains the general lack in bargaining power among farmers when dealing with purchasing representative of the processor-butcher.

Table 6. Descriptive statistics for public goods and services available to farmers $(\mathrm{S}=328)$.

\begin{tabular}{|c|c|c|c|c|c|c|c|c|c|}
\hline \multirow[t]{3}{*}{ Variable } & \multirow[t]{3}{*}{ Categories } & \multicolumn{6}{|c|}{ Market Outlet } & \multicolumn{2}{|c|}{ Total } \\
\hline & & \multicolumn{2}{|c|}{ Feedlotter } & \multicolumn{2}{|c|}{ Processor-Butcher } & \multicolumn{2}{|c|}{ Direct } & \multirow[b]{2}{*}{ Freq. } & \multirow[b]{2}{*}{$\%$} \\
\hline & & Freq. & $\%$ & Freq. & $\%$ & Freq. & $\%$ & & \\
\hline \multirow[t]{3}{*}{ Pasture availability } & Insufficient & 11 & 57.89 & 67 & 39.41 & 75 & 53.96 & 153 & 46.65 \\
\hline & Sufficient & 8 & 42.11 & 103 & 60.59 & 64 & 46.04 & 175 & 53.35 \\
\hline & Overall & 19 & 100 & 170 & 100 & 139 & 100 & 328 & 100 \\
\hline \multirow[t]{3}{*}{ Farm credit } & No & 17 & 89.47 & 132 & 77.65 & 124 & 89.21 & 273 & 83.23 \\
\hline & Yes & 2 & 10.53 & 38 & 22.35 & 15 & 10.79 & 55 & 16.77 \\
\hline & Overall & 19 & 100 & 170 & 100 & 139 & 100 & 328 & 100 \\
\hline \multirow[t]{3}{*}{ Cooperative } & No & 18 & 94.74 & 159 & 93.53 & 128 & 92.09 & 305 & 92.99 \\
\hline & Yes & 1 & 5.26 & 11 & 6.47 & 11 & 7.91 & 23 & 7.01 \\
\hline & Overall & 19 & 100 & 170 & 100 & 139 & 100 & 328 & 100 \\
\hline
\end{tabular}

\subsection{Drivers of market outlet choice}

The Multinomial Logit Model was run using STATA 15, for a sample of 328 beef cattle farmers to determine the drivers of market outlet choice among farmers. The model fit statistics suggested statistical significance at $\mathrm{p}<$ 0.000 , with a Wald $\chi^{2}(56)$ of 1410.35 , Log pseudolikelihood statistic of -149.900 and a Pseudo $\mathrm{R}^{2}$ statistic of 0.477 . The market outlet alternatives with the highest frequency, Processor-Butcher, was used as a reference during the analysis and the results are presented in Table 7.

4.2.1 Farmer Socioeconomic Factors

Generally, the result indicate that socioeconomic characteristics do not have significant influence on the farmers' market outlet choice decision. Only off-farm employment revealed a positive and statistically significant $(p<$ 0.05 ) relationship with the market outlet choice of feedlotter over the processor-butcher, which is consistent with 
the expectation. Being engaged in off-farm employment increases the probability of marketing cattle through the feedlotter outlet over the processor-butcher by $7.6 \%$. Feedlotters provide time and place utility (Tefera, 2014) for farmer that lack sufficient time for farm production and marketing functions due to engagement in off-farm employment (Hao et al., 2018).

Table 7. Multinomial Logit Model results $(\mathrm{S}=328)$.

\begin{tabular}{|c|c|c|c|c|c|c|}
\hline \multirow[t]{2}{*}{ Variable } & \multicolumn{3}{|c|}{ Feedlotter } & \multicolumn{3}{|c|}{ Direct } \\
\hline & $\beta$ & Robust Std. Err & $\mathrm{dy} / \mathrm{dx}$ & $\beta$ & Robust Std. Err & $\mathrm{dy} / \mathrm{dx}$ \\
\hline \multicolumn{7}{|c|}{ Farmer Socioeconomic Factors } \\
\hline Age & 3.040 & 2.552 & 0.087 & -0.823 & 1.074 & 0.129 \\
\hline Education & 0.115 & 0.828 & 0.005 & -0.265 & 0.316 & 0.034 \\
\hline Gender & -0.950 & 1.611 & 0.027 & 0.246 & 0.464 & 0.039 \\
\hline Marital status & 0.795 & 1.958 & 0.017 & 0.474 & 0.473 & 0.051 \\
\hline Experience & 1.155 & 0.815 & 0.030 & 0.014 & 0.348 & 0.009 \\
\hline Household size & -0.158 & 0.826 & 0.007 & 0.295 & 0.419 & 0.038 \\
\hline Off-Farm employment & 2.889 & 1.383 & $0.076^{* *}$ & -0.022 & 0.458 & 0.029 \\
\hline \multicolumn{7}{|c|}{ Public Goods and Services Factors } \\
\hline Pasture availability & -2.123 & 1.012 & $0.048 *$ & -0.884 & 0.334 & $0.090 * *$ \\
\hline Access farm credit & -0.950 & 1.024 & 0.021 & -0.388 & 0.542 & 0.039 \\
\hline Cooperative member & 0.655 & 1.236 & 0.008 & 0.977 & 0.499 & $0.115^{*}$ \\
\hline \multicolumn{7}{|c|}{ Price and Market-related Factors } \\
\hline Market distance & -1.643 & 1.003 & 0.031 & -1.308 & 0.442 & $0.147 * * *$ \\
\hline Source market info. & -0.988 & 0.895 & 0.034 & 0.892 & 0.363 & $0.119 * * *$ \\
\hline Marketing cost & -1.129 & 0.635 & $0.028 *$ & -0.192 & 0.166 & 0.013 \\
\hline Cattle sold & 3.717 & 1.076 & $0.109 * * *$ & -1.234 & 0.752 & $0.186^{* *}$ \\
\hline Price & -9.857 & 2.140 & $0.221 * * *$ & -4.139 & 0.999 & $0.421 * * *$ \\
\hline Sale duration & 14.903 & 1.038 & $0.416 * * *$ & -2.748 & 0.463 & $0.474 * * *$ \\
\hline Price setting & 1.405 & 0.945 & 0.022 & 1.646 & 0.538 & $0.190 * * *$ \\
\hline \multicolumn{7}{|c|}{ Production-related Factors } \\
\hline Total costs & 0.766 & 0.406 & 0.017 & 0.365 & 0.178 & $0.038^{*}$ \\
\hline Labourers & 1.416 & 0.930 & 0.028 & 1.065 & 0.469 & $0.119 * *$ \\
\hline Herd size & -3.714 & 1.752 & $0.105 * *$ & 0.866 & 0.771 & 0.141 \\
\hline Supplement feed & -0.149 & 0.121 & 0.002 & -0.160 & 0.074 & $0.018 * *$ \\
\hline Medicines & 1.052 & 0.518 & $0.034 * *$ & -0.653 & 0.300 & $0.090 * * *$ \\
\hline \multicolumn{7}{|c|}{ Herd Features } \\
\hline Breed type & 1.156 & 0.975 & 0.031 & -0.066 & 0.383 & 0.019 \\
\hline Calving rate & -2.261 & 2.417 & 0.071 & 1.282 & 0.885 & 0.179 \\
\hline Cows & -14.845 & 9.948 & 0.477 & 9.646 & 5.132 & $1.325 * *$ \\
\hline Heifers & 1.642 & 4.433 & 0.044 & -0.143 & 1.739 & 0.032 \\
\hline Steers & -8.937 & 8.239 & 0.224 & -1.120 & 2.415 & 0.057 \\
\hline Oxen & -2.717 & 1.467 & $0.070 *$ & -0.178 & 0.409 & 0.003 \\
\hline
\end{tabular}

Note: Reference category $=$ Processor-Butcher. Significance levels: $* p<0.1,{ }^{* *} p<0.05, * * * p<0.01$.

4.2.2 Public Goods and Services

The perception of sufficient communal pasture availability is negatively and statistically significant related to the farmers' market outlet choice decisions of feedlotter and direct market channels compared to the processor-butcher outlet, significant at $p<0.1$ and $p<0.05$, respectively. Farmers who perceive themselves to be having sufficient communal pastures for cattle production are less likely to select the feedlotter and the direct outlets, compared to the processor-butcher, by $4.8 \%$ and $9 \%$, respectively. The results imply that protecting and increasing communal pastures is key for increased market participation through intensive commercial outlet (processor-butcher). This is critically vital for the exploitation of agribusiness opportunities available through the domestic and export markets. Beef exports to the EU declined from 703.25 tonnes in 2016 to 27.62 tonnes in 2018, alluding to a beef export agribusiness opportunity (Department of Veterinary and Livestock Services, 2018a).

Being a co-operator reveals a positive and statistically significant $(p<0.1)$ relationship with the farmer's choice of the direct market outlet compared to the processor-butcher, which is consistent with the expectation. Cooperators relative to non-co-operators, are $11.5 \%$ more likely to market through the direct outlet over the processorbutcher, ceteris paribus. This is attributed to gain in bargaining power through cooperativism, emphasizing the importance of cooperatives in arranging and establishing better agricultural markets and prices for farmers (Bijman \& Iliopoulos, 2014) 


\subsubsection{Price and Marketing Factors}

The results reveal that this category is the main vector of the drivers of the market outlet choice decision. As expected, market distance indicates a negative but statistically significant $(p<0.01)$ relationship with the farmers' choice of the direct market outlet over the processor-butcher. The results imply that for an additional kilometre unit increase in market distance, the probability of marketing through the direct outlet decreases by $14.7 \%$ relative to the processor-butcher outlet. It is popular in the study area that purchasing representatives from processorbutcher scout cattle from communities far away from commercial markets. This increases the probability of farmers in remote communities to transact through the processor-butcher outlet, compared to direct sales that require more time scouting for buyers.

As expected, sourcing market information through informal sources over formal sources increases the probability of selecting the direct market outlet by $11.9 \%$ relative to the processor-butcher channel, significant at $p<0.05$. Marketing cost is statistically significant at $p<0.1$, revealing a negative relationship with farmers' choice of feedlotter over the processor-butcher outlet. The results indicate for a given one Emalangeni unit increase in marketing cost, the probability of marketing through the feedlotter outlet decrease by $2.8 \%$ compared to processorbutcher, ceteris paribus. As expected, farmers shy away from the feedlotter as marketing costs escalate, preferring the processor-butcher who visit communities to scout and purchase cattle, thereby inheriting the larger proportion of the marketing cost.

Number of cattle sold reveals a positive and statistically significant $(p<0.01)$ relationship with the farmers' choice of feedlotter outlet, well to our expectation. For a one-unit increase in the number of cattle sold, the likelihood of marketing through the feedlotter increases by $10.9 \%$ compared to the processor-butcher. Mass marketing of younger classes of cattle (yearlings, steers and heifers) to feedlotters is popular in the study area, relative to the processor-butcher who base prices on live weight. Consistent with Ndoro et al. (2015), increases in the quantity of marketed cattle by one herd decreases the probability of selecting the direct market channel, significant at $p<0.05$. This implies that farmers tend to transact through the processor-butcher who is often willing to purchase more cattle at per transaction.

Selling price indicates a negative connotation with the farmers' decisions of feedlotter and direct market outlets, significant at $p<0.01$ for both outlets. This reflects that for a given one Emalangeni unit increase in selling price, the probability that a farmer selects the feedlotter over the processor-butcher decreases by $22.1 \%$. The same conclusion is drawn regarding the direct market outlets, but with a $42.1 \%$ decrease. This implies that as the selling price increases, farmers tend to use the processor-butcher market channel, over the other outlets. This is logical as the processor-butcher visit communities scouting for cattle under sale, reducing the marketing costs for the farmers (Verhaegen \& Van Huylenbroeck, 2001), as well as eliminating the hurdles involved in the search for buyers by the farmers. This improves farmers' utility and willingness participate in the formal agribusiness that takes advantage of the domestic and cross-border beef marketing. Moreover, as increased prices impose a pull-factor on cattle offered for sale, the processor-butcher is the most readily available outlet to absorb more cattle at a time to reduce the cost of beef importation.

Sale duration exhibits a significant positive relationship $(p<0.01)$ with the farmer's choice of feedlotter and significant negative relationship $(p<0.01)$ with the choice of direct market outlet. The results reveal that for shorter durations (within 2 weeks) over longer durations (more than 2 weeks), the likelihood of a farmer to transact through the feedlotter increases by $41.6 \%$ over the producer-butcher. Consistent with Gong et al. (2006), the results imply that for urgent sales of younger cattle classes, farmers tend to use the fast-paying community-based feedlotter over the processor-butcher that exhibit delayed purchases since they scout the community once-a-week in summer and fortnightly in winter, at the dip-tank. The results further reveal that regarding shorter sale durations over longer durations, the probability of selecting the direct outlet compared to processor-butcher decreases by $47.4 \%$, ceteris paribus. This means that for urgent slaughter sales, farmers tend to use the processor-butcher outlet over the direct outlet that demands longer sale durations.

For transactions where farmers use their own experience to set prices, relative to when assisted, the likelihood of a farmer to select the direct market outlet increases by $19 \%$ compared to the processor-butcher outlet (significant at $p<0.01$ ). This means that pricing knowledgeable farmers tend to use the direct market outlet since they have market information that boosts their bargaining power. This increases market incentives compared to the processor-butcher outlet.

4.2.4 Production-related Factors

Total cost captures that level of investment injected in the production and marketing processes. The variable reveals positive and statistically significant $(p<0.1)$ relationship with farmers' choices of direct outlet. For a one Emalangeni unit increase in investment, the probability of selecting the direct outlet relative to processor-butcher, increases by $3.8 \%$, ceteris paribus. Due to gain in bargaining power, farmers often select the direct outlet, where they derive higher prices that justify their investment.

For a given increase by one labourer, the probability of choosing the direct market outlet relative to the processor-butcher, increases by $11.9 \%$, significant at $p<0.05$. A negative and significant $(p<0.05)$ relationship 
is observed with regards to herd size and the choice of feedlotter outlet. This means that for a unit increase in the value of herd size, the likelihood of marketing through the feedlotter over processor-feedlotter decreases by $10.5 \%$, holding other factors constant. This implies that farmers with high estimated value of the herd are less likely to select the feedlotter outlet, but prefer the processors-butcher. The reason is that the feedlotter incurs livestock finishing cost, which reduces the cattle market price compared to the processor-butcher that base prices on live weight for direct slaughters.

As expected, a one-unit $(\mathrm{kg})$ increase in the amount of supplement feed imposes a $1.8 \%$ decrease in the probability of selecting the direct outlet over the processor-butcher outlet, significant at $p<0.05$. Moreover, a unit increase in medicines used imposes a 3.4\% increase on the farmer's probability to transact through the feedlotter outlet. In addition, a 9\% decrease in the probability of transacting through the direct outlet over the processorbutcher is observed concerning a unit increase in the volume of medicine used. In line with Gillespie et al. (2004), the results imply that the farmers who use more supplement feed and medicines are more likely to select formal outlet alternatives (processor-butcher and feedlotter) over the informal (direct) outlet.

4.2.5 Herd Features

For a unit increase in the proportion of cows in the herd, the likelihood of a farmer to select the direct outlet increases by $132.5 \%(p<0.05)$, relative to the processor-butcher. This is because cows are valuable breeding stock, often sold as retired stock, thereby attracting lower prices through the processor-butcher. Therefore, farmers tend to transact retired cows of poor market value through the direct outlet for home slaughter where beef quality is not of major concern. Moreover, given a unit increase in the proportion of oxen in the herd, the probability that a farmer transacts through the feedlotter decreases by $7 \%$ relative to the processor-butcher, significant at $p<0.1$. The logic behind the results is that oxen often carry more live weight, thus suitable for sale through the formal processor-butcher commercial outlet, as opposed to feedlotters. The results are in line with Mafukata (2015) who found that increased cattle productivity is associated with market participation through formal outlets.

\section{Conclusions}

Based on the findings, the study concludes that formal education and the use of high-quality exotic breeds are critical for the shift towards intensive beef production and marketing through formal market outlets. This is necessary for the advancement of rural livelihoods through formal domestic and cross-border marketing outlets. It is, therefore, recommended that farmer training be offered through the Department of Livestock Extension Services. Cooperativism is identified as the missing link required for the generation of bargaining power for smallholder farmer, to identify and establish pro-poor market outlets that offer better prices for farmers. Farmers are encouraged to take a business-unusual approach to embrace cooperativism as a livelihood improvement strategy.

Moreover, pasture availability is found to be associated with participation in vigorous beef market outlets through domestic and export market outlet (processor-butcher). Therefore, traditional authorities are encouraged to protect and ensure that existing communal pastures are sufficient for cattle farming, to promote market participation in intensive market outlets. This is critical for rural and national economic growth in Eswatini.

Price and market-related factors and production-related factors constitute the main vectors of the drivers of market outlet choice in cattle marketing. A pro-poor market system must be established to propagate conducive market outlets. Production of high-value classes of cattle (cows and oxen) must be encouraged to improve cattle marketing through feedlotter and direct market outlets.

\section{Recommendations for future research}

The establishment of pro-poor market outlets requires further market research with respect to market structure organisation and farmer coordination strategies. The existing cash crop and vegetable production and marketing systems, which are vertically coordinated by inclusive statutory and regulatory bodies, can be used as reference in this regard. Further research is also desired regarding the establishment and management of beef cattle farmers' cooperatives to resolve issues relating to cooperative resilience through an economically viable cooperative system. This is fundamental in the rearrangement and mobilization of the often lacking capital resources to build a production and marketing system that awards considerable bargaining power to farmers. Moreover, this is important for the development of a competitive strategy, for farmers, in the beef cattle market. Last, research on production and marketing efficiency is desired to increase the production of marketable surplus required for improved market participation through formal intensive market outlet that take advantage of the domestic and export beef demand. This will enhance the shift towards vigorous market participation that improves farmer' income and livelihoods.

\section{References}

Agbeko, N. (2015). On the Characteristics of the free market in a cooperative society. arXiv preprint arXiv:1506.03917 
Aguglia, L., De Santis, F., \& Salvioni, C. (2009). Direct selling: a marketing strategy to shorten distances between production and consumption. Paper presented at the 113th European Association of Agricultural Economists (EAAE) Seminar "A resillient European food industry and food chain in a challenging world", Chania, Crete, Greece, 3-6 September

Barrett, C. B. (2008). Smallholder market participation: Concepts and evidence from eastern and southern Africa. Food Policy, 33(4), 299-317. doi:10.1016/j.foodpol.2007.10.005

Bijman, J., \& Iliopoulos, C. (2014). Farmer's cooperatives in the EU: Policies, srategies and organization Annals of Public and Cooperative Economics, 85(4), 497-508

Blandon, J., Henson, S., \& Islam, T. (2009). Marketing preferences of small-scale farmers in the context of new agrifood systems: A stated choice model. Agribusiness, 25(2), 251-267

Central Statistics Office. (2018). National Accounts Estimates. Ministry of Economic Planning and Development, Government of Eswatini: Mbabane, Eswatini

Chalwe, S. (2011). Factors influencing bean producers' choice of marketing channels in Zambia. M.Sc. Thesis. University of Zambia. Zambia

Coetzee, L., Montshwe, B., \& Jooste, A. (2005). The marketing of livestock on communal lands in the Eastern Cape Province: contraints, challenges and implications for the extension services. South African Journal of Agricultural Extension, 34(1), 81-103

De Bruyn, P., De Bruyn, J., Vink, N., \& Kirsten, J. F. (2001). How transaction costs influence cattle marketing decisions in the northern communal areas of Namibia. Agrekon, 40(3), 405-425

Department of Veterinary and Livestock Services. (2018a). Animal Production Annual Report. Ministry of Agriculture, Government of Eswatini: Mbabane, Eswatini

Department of Veterinary and Livestock Services. (2018b). Annual Livestock Census. Ministry of Agriculture, Government of Eswatini: Mbabane, Eswatini

Dlamini-Mazibuko, B. P., Ferrer, S., \& Ortmann, G. (2019). Factors affecting the choice of marketing outlet selection strategies by smallholder farmers in Swaziland. African Journal of Science, Technology, Innovation and Development, 11(5), 569-577

Dlamini, S. I., \& Huang, W.-C. (2019). A double hurdle estimation of sales decisions by smallholder beef cattle farmers in Eswatini. Sustainability, 11(19), 5185

Emana, B., Ketema, M., Mutimba, J. K., \& Yousuf, J. (2015). Factors affecting market outlet choice of potato producers in Eastern Hararghe Zone, Ethiopia. Journal of Economics and Sustainable Development, 6(15), $159-172$

FAO. (2005). AQUASTAT Country Profile - Swaziland. FAO: Rome, Italy

Fertö, I., \& Szabó, G. (2002). The Choice of supply channels in Hungarian fruit and vegetable sector, senior research fellow and research fellow institute of economics. Paper presented at the Hungarian Academy of Sciences Annual Meeting of the American Agricultural Economics Association in Long Beach, California, U.S.A. 15 May

Gillespie, J. M., Basarir, A., \& Schupp, A. R. (2004). Beef producer choice in cattle marketing. Journal of Agribusiness, 22(2), 149-161

Girma, M., \& Abebaw, D. (2012). Patterns and determinants of livestock farmers' choice of marketing channels: micro-level evidence. Working Paper No. 1. Ethiopian Economics Association, Ethiopian Economics Policy research Institute, Ethiopia

Gong, W., Parton, K., Cox, R. J., \& Zhou, Z. (2007). Transaction costs and cattle farmers' choice of marketing channels in China. Management Research News, 30(1), 47-56.

Gong, W., Parton, K., Zhou, Z.-Y., \& Cox, R. J. (2006). Marketing channel selection by cattle farmers in China: A transaction cost approach. Paper presented at the International Conference on "Emerging China: Internal Challenges and Global Implications", Victoria University, Melbourne, Australia, 13-14 July

Government of Eswatini. (1965). The Animal Disease Act. Ministry of Agriculture, Government of Eswatini: Mbabane, Eswatini

Greaves, B. B. (1975). Free Market Economics: A Basic Reader. New York, U.S.A: The Foundation for Economic Education, Inc.

Greene, W. H. (2012). Econometric Analysis (7th Ed.). Essex, England: Pearson Education Limited, Prentice Hall.

Hailu, C., \& Fana, C. (2017). Determinants of market outlet choice for major vegetables crop: Evidence from smallholder farmers of Ambo and Toke-Kutaye Districts, West Shewa, Ethiopia. International Journal of Agricultural Marketing, 4(2), 161-169

Hao, J., Bijman, J., Gardebroek, C., Heerink, N., Heijman, W., \& Huo, X. (2018). Cooperative membership and farmers' choice of marketing channels: Evidence from apple farmers in Shaanxi and Shandong Provinces, China. Food Policy, 74, 53-64

Hobbs, J. E. (1997). Measuring the importance of transaction costs in cattle marketing. American Journal of Agricultural Economics, 79(4), 1083-1095 
Hoffman, S. D., \& Duncan, G. J. (1988). Multinomial and conditional logit discrete-choice models in demography. Demography, 25(3), 415-427

Mabuza, M. L., Ortmann, G., \& Wale, E. (2014). Effects of transaction costs on mushroom producers' choice of marketing channels: Implications for access to agricultural markets in Swaziland. South African Journal of Economic and Management Sciences, 17(2), 01-13

Mafukata, M. A. (2015). Factors having the most significance on the choice and selection of marketing channels amongst communal cattle farmers in Vhembe District, Limpopo Province. Journal of Human Ecology, 49(12), $77-87$

Mailu, S., Wachira, M., Munyasi, J., Nzioka, M., Kibiru, S., Mwangi, D., Kaguthi, P. \& Kithome, L. (2012). Influence of prices on market participation decisions of indigenous poultry farmers in four districts of Eastern Province, Kenya. Journal of Agriculture and Social Research, 12(1), 1-10

Ministry of Labour and Social Security. (2013/14). The Swaziland Integrated Labour Force Survey. Ministry of Labour and Social Security, Government of Eswatini: Mbabane, Eswatini

Mutura, J. K., Nyairo, N., Mwangi, M., \& Wambugu, S. K. (2015). Vertical and horizontal integration as determinants of market channel choice among smallholder dairy farmers in lower Central Kenya. Asian Journal of Economics and Empirical Research, 2(2), 83-90

Ndoro, J. T., Mudhara, M., \& Chimonyo, M. (2015). Farmers' choice of cattle marketing channels under transaction cost in rural South Africa: A multinomial logit model. African Journal of Range \& Forage Science, 32(4), 243-252

Ngarava, S., Phetshe, M., \& Mushunje, A. (2019). Market awareness and participation for cattle farmers in the Kaonafatso ya Dikgomo (KyD) Scheme in KwaZulu-Natal Province, South Africa. Agriculture, 9(10), 215

Shiimi, T., Taljaard, P. R., \& Jordaan, H. (2012). Transaction costs and cattle farmers' choice of marketing channel in North-Central Namibia. Agrekon, 51(1), 42-58

Soe, W. P. P., Moritaka, M., \& Fukuda, S. (2015). An analysis of the factors influencing marketing channel choice by paddy rice farmers in Myanmar. Journal of the Faculty of Agriculture, Kyushu University, 60(2), 535-542

Tefera, T. (2014). Analysis of chickpea value chain and determinants of market options choice in selected districts of southern Ethiopia. Journal of Agricultural Science, 6(10), 26-40

Tesfamariam, K., Berhanu, T., \& Afera, A. (2015). Determinants of the choice of marketing channel among smallscale honey producers in Tigray Region, Ethiopia. Journal of Business Management and Social Sciences Research, 4(4), 295-305

Verhaegen, I., \& Van Huylenbroeck, G. (2001). Costs and benefits for farmers participating in innovative marketing channels for quality food products. Journal of Rural Studies, 17(4), 443-456

Woldie, G. A., \& Nuppenau, E. (2009). Channel choice decision in the Ethiopian banana markets: A transaction cost economics perspective. Journal of Economic Theory, 3(4), 80-90

Wooldridge, J. M. (2013). Introductory econometrics: A modern approach (5th Ed.): Nelson Education, Ltd.

Xaba, B. G., \& Masuku, M. B. (2013). Factors affecting the choice of marketing channel by vegetable farmers in Swaziland. Sustainable Agriculture Research, 2(1), 112-123

Zivenge, E., \& Karavina, C. (2012). Analysis of factors influencing market channel access by communal horticulture farmers in Chinamora District, Zimbabwe. Journal of Development and Agricultural Economics, $4(6), 147-150$ 